\title{
Virus surveys of commercial vineyards show value of planting certified vines
}

In the North Coast wine-growing region, mixed infections were predominant in older vineyards, while recently planted certified vines did not have mixed infections.

by Kari L. Arnold, Neil McRoberts, Monica L. Cooper, Rhonda Smith and Deborah A. Golino

\section{Abstract}

Viruses are of great concern in vineyards. They cost the California wine grape industry as much as $\$ 91,661$ per acre over the life of a vineyard, according to a 2015 economic study of the North Coast wine-growing region. As a first step toward managing viruses, growers are encouraged to plant certified material regulated by the California Grapevine Registration and Certification program. There are risks in sourcing plant material from stocks that are not subject to the same level of regulation. We surveyed vineyards of varying ages for eight common viruses to demonstrate the value of selecting certified material for new plantings.
Author Kari Arnold examines a virus-positive vine at a UC Davis research project. Viruses cost the California wine grape industry as much as $\$ 91,661$ per acre over the life of a vineyard. Planting certified material regulated by the California Grapevine Registration and Certification program is a first step toward managing viruses.

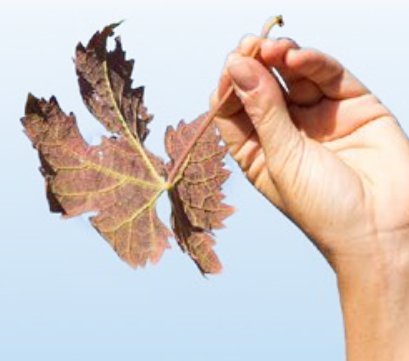

G rapevines have the highest number of viruses and virus-like diseases ever discovered in a single crop (Martelli 2014), and they may cost California wine grape growers as much as $\$ 91,661$ per acre over the life of a vineyard (Ricketts et al. 2015) by affecting yield, color, sugar and other qualitative parameters (Goheen and Cook 1959). Some viruses are spread by insects and nematodes (Golino et al. 2002; Raski and Hewitt 1960), but human activities such as the propagation of infected material also distribute viruses into vineyards. Viruses are graft transmissible, meaning they can move from scion to rootstock, or from rootstock to scion during topworking (Alley and Golino 2000; Olmo 1951).

Online: https://doi.org/10.3733/ca.2019a0006

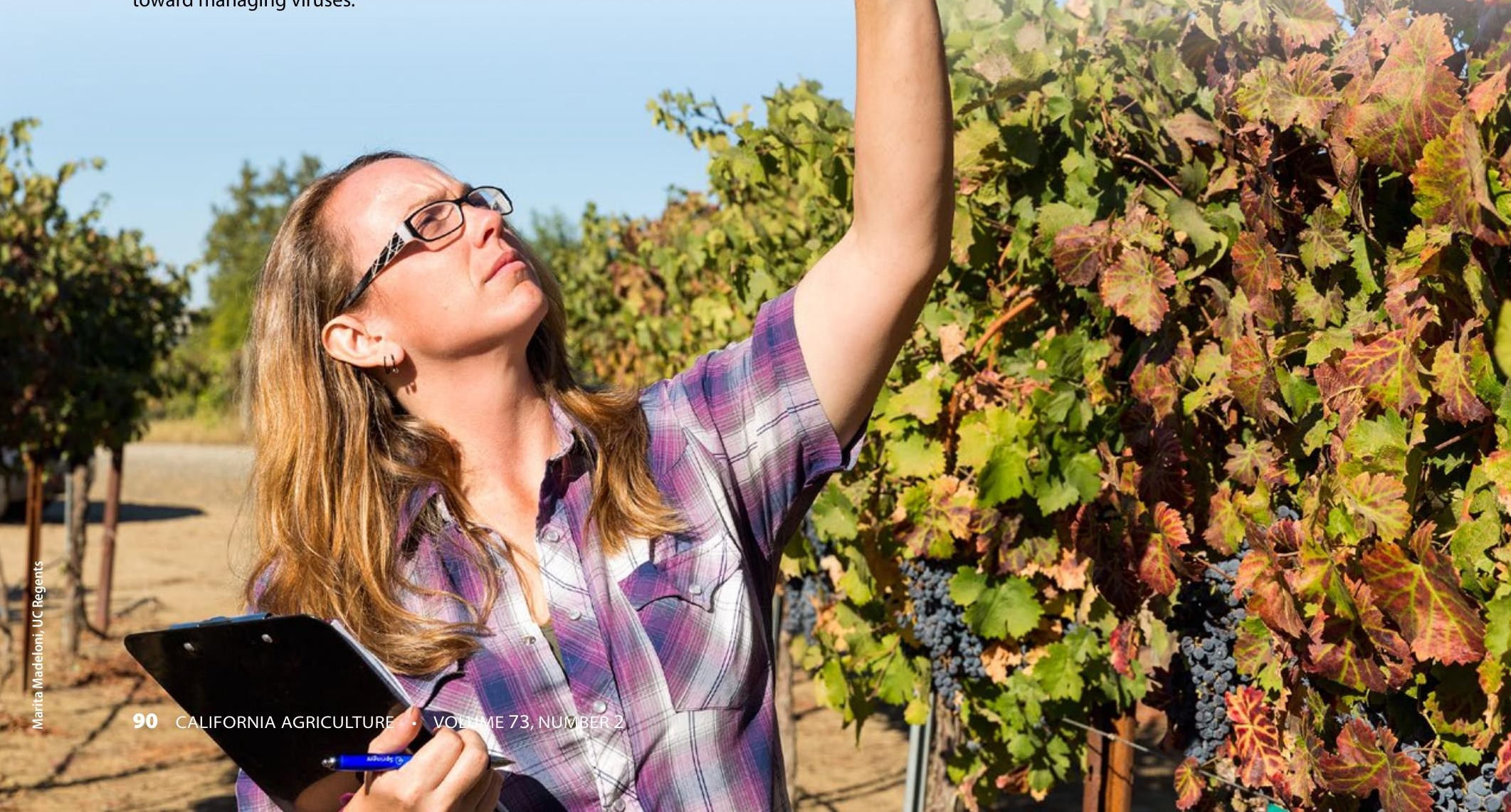




\section{CGR\&C program}

The first step in virus management is sourcing virusscreened material. Under the auspices of the California Grapevine Registration and Certification (CGR\&C) program (www.cdfa.ca.gov/plant/pe/nsc/nursery/ grapevine.html), virus-screened material is provided through a systematic supply chain regulated by the California Department of Food and Agriculture (CDFA): CGR\&C-certified vines are derived from registered nursery increase blocks where samples are collected and screened for viruses on a rotational basis and maintained in accordance with CDFA guidelines; the vines in registered nursery increase blocks are derived from foundation material at the Foundation Plant Services (FPS) department at UC Davis, where every vine is screened on a rotational basis and maintained in accordance with CDFA guidelines (Golino et al. 2017). Since its establishment in the 1950s, the CGR\&C program has grown to provide an economic benefit of up to $\$ 50$ million per year for the North Coast region alone (Fuller et al. 2015).

Virus screened, however, does not mean virus free; unknown viruses may not be detected and some viruses may not have a negative impact on the crop (Al Rwahnih, Rowhani et al. 2015; Al Rwahnih et al. 2013; Al Rwahnih et al. 2016).

Screening activities occur at different points in the supply chain. The initial screening of a grapevine selection is a series of biological assays designed to detect disease symptoms related to certain detrimental virus diseases (Rowhani et al. 2005). These assays require the grafting of the selection onto healthy indicator vines. If certain viruses are present in the selection, the indicator vines will indicate virus infection by developing disease symptoms (Rowhani et al. 2005). For example, red, rolling leaves in the Cabernet Franc indicator assay is indicative of grapevine leafroll disease.

Material that passes the initial screening is tested by DNA analysis to ensure it is true to type, then advanced to foundation status and planted into the foundation vineyard at FPS. That vineyard is subject to spring and fall inspections, and every vine is tested on a rotational basis using PCR (polymerase chain reaction) assays and ELISA (enzyme linked immunosorbent assay) because viruses can enter the vineyard by way of insects and other vectors.

Registered increase block material at commercial nurseries originates from foundation material, and therefore it does not need to be subjected to biological assays. However, virus-specific assays such as PCR and ELISA are used to repeatedly sample the blocks, and visual inspections are made to monitor the virus status of the plant material. PCR and ELISA are reliable assays, but their specificity is a drawback: They give positive results only for known viruses and virus strains, not for unknown viruses. When grapevine red blotch virus (GRBV) and grapevine Pinot gris virus (GPGV) were recently discovered, they had to be sequenced before researchers could construct new diagnostic assays to detect them (Al Rwahnih et al. 2013; Al Rwahnih et al. 2016).

GRBV was discovered in 2013 (Al Rwahnih et al. 2013), but the testing of a dried leaf sample collected from Sonoma County and stored in the UC Davis herbarium for 70 years dates the presence of GRBV in California as far back as 1940 (Al Rwahnih, Rowhani et al. 2015), when that leaf sample was first collected by Dr. Harold Olmo, a UC Davis professor of viticulture. GRBV shares common symptoms with grapevine leafroll disease, which is caused by multiple grapevine leafroll associated viruses (GLRaV-1, -2, -3, -4 and -7 ). These virus diseases were likely detected as a single disease by the biological assay due to similar symptomology. Vine selections showing leafroll-like symptoms, whether they were infected with GRBV or GLRaVs, would not have advanced into the foundation vineyard at FPS. Yet, if GRBV were somehow introduced to a registered increase block, the virus could go undetected because a more virus-specific screening assay like ELISA or PCR for GLRaV-3 would not detect it.

Grower concern, as well as recent work involving economic impacts (Ricketts et al. 2017), led to the addition of GRBV to the regulations of the CGR\&C

Right, the initial screening of a grapevine selection requires the grafting of the selection onto healthy indicator vines. If certain viruses are present in the selection, the indicator vines will develop disease symptoms. Material that passes initial screenings is tested by virus-specific assays such as PCR and ELISA (below, ELISA plate with sample).

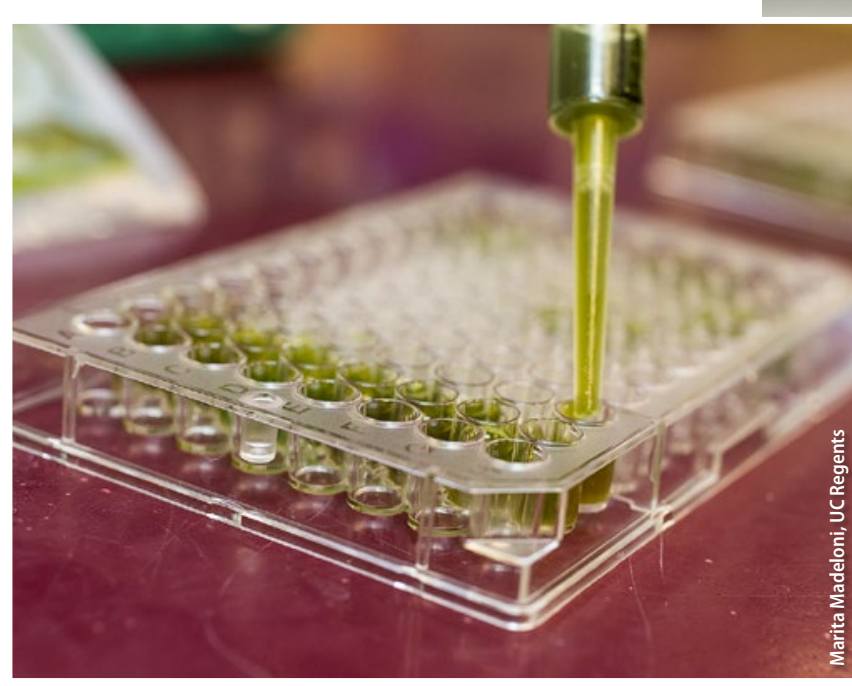


program and the addition of PCR detection techniques because GRBV is not detectable by ELISA methods. Using PCR-based assays increases efficiency by screening a sample for multiple viruses at once and enhances reliability by screening registered increase blocks for viruses not previously targeted. The updated sampling protocol also provides analytics to measure success and facilitate future improvements (Arnold et al. 2017; McRoberts et al. 2003). With the support of industry stakeholders, FPS has also invested in genetic sequencing technology to improve unknown virus detection in plant material (Al Rwahnih, Daubert et al. 2015).

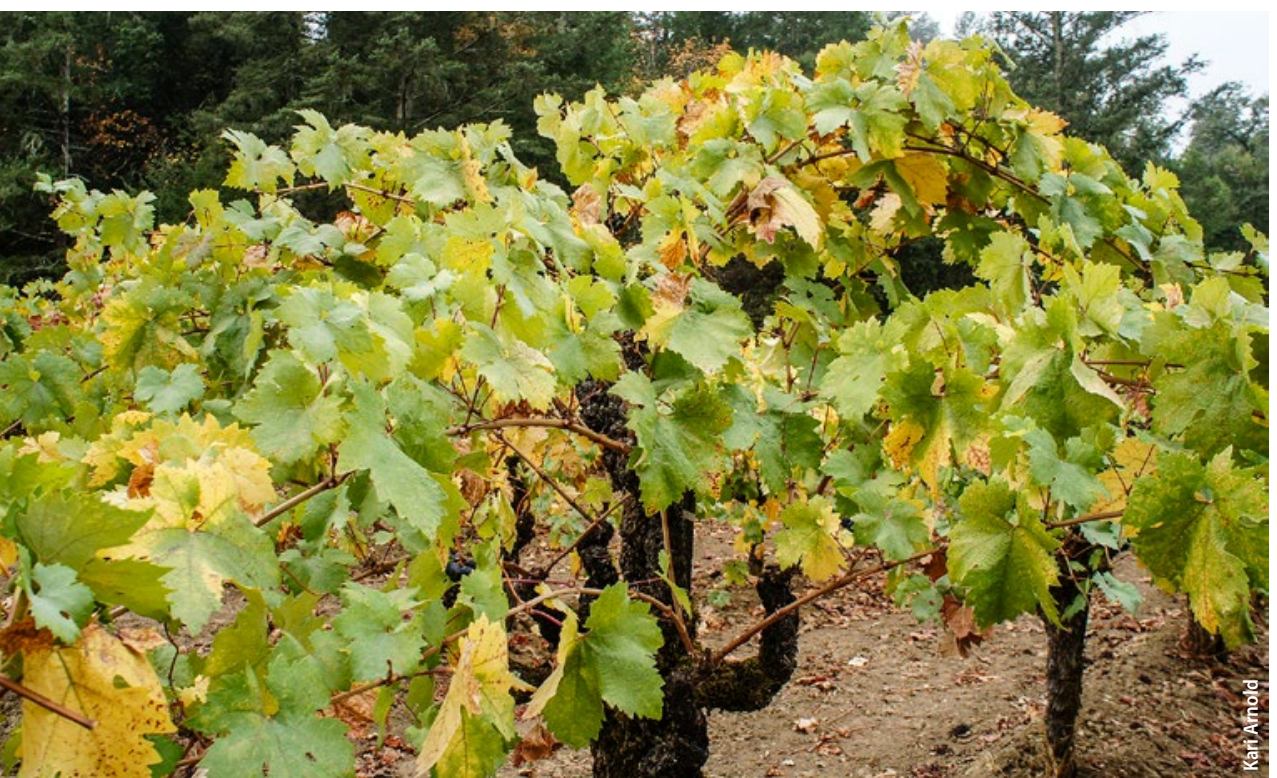

Zinfandel grafted to St. George rootstock appears healthy, although it is infected with GLRaV-2 and grapevine virus $A$ and $B$.
There are great risks in selecting material for new vineyard plantings from sources that are not subject to the same level of regulation as the CGR\&C program. Multiple viruses spread naturally in the vineyard by way of insects and nematodes, and the longer a vine remains exposed to nearby infected vines and their virus vectors, the more likely that vine is to be infected (Arnold et al. 2017). For example, mealybugs and some scale insects spread GLRaV-3, and dagger nematodes (Xiphinema index) spread grapevine fanleaf virus (GFLV). To demonstrate the risks of not using certified planting material, we surveyed commercial wine grape

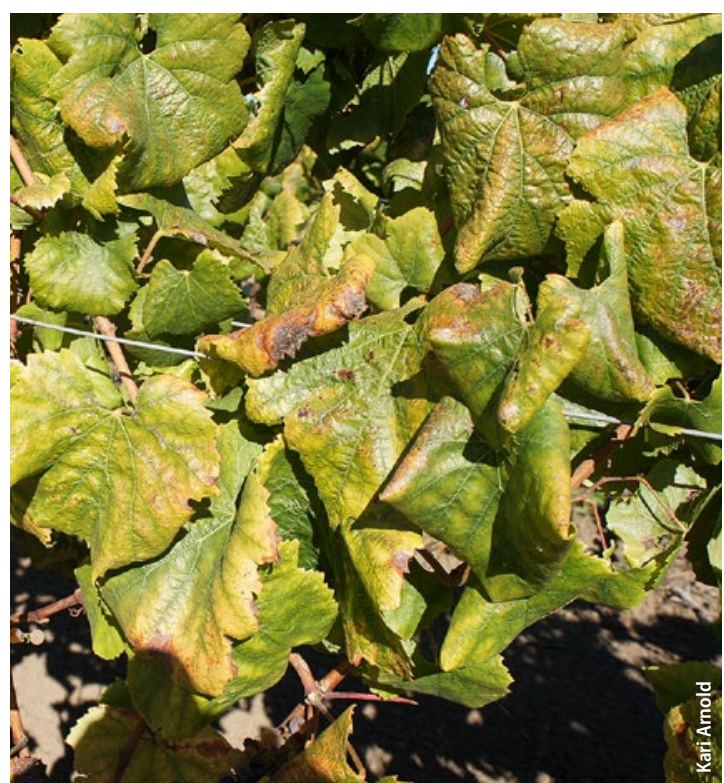

Chardonnay infected with both GLRaV-3 and GRBV.
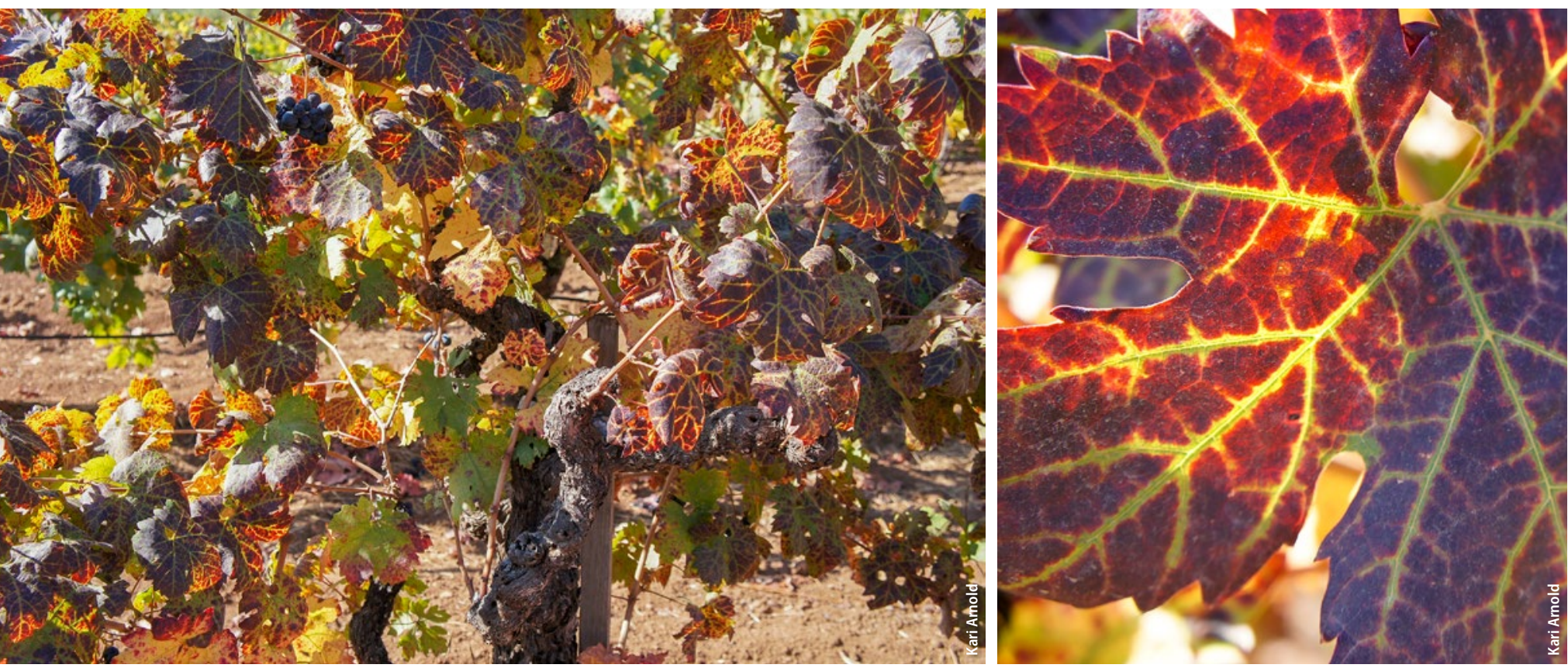

Red variety infected with GLRaV-2 andGLRaV-3 (left), and grapevine viruses A and B (leaf closeup, right). 
vineyards of varying age and origin and screened for viruses regulated by the CGR\&C program.

\section{Survey of 24 vineyards}

We selected vineyards for the survey based on the history of grapevine material in the North Coast region of California and defined them by planting year range: 1880-1980, 1981-1995, 1996-2010 and 2011-2014 (table 1). We surveyed 24 vineyards in the Carneros, Oakville, Rutherford, Calistoga and St. Helena viticulture areas in the Napa Valley and the Healdsburg region of Sonoma County to account for multiple regions.

We collected five to 15 vine samples, including both white- and red-fruited varieties, from 27 to 29 randomly selected blocks in each planting year range. Sample size was adjusted to account for variability in block size, which ranged from 2 to 20 acres. Vines expressing symptoms and also vines not expressing symptoms were sampled. A total of 980 samples were collected from 112 blocks. Survey collection began in August 2014 and continued for 3 months. We sampled in a W pattern in the field to account for spatial patchiness in the incidence of the viruses (Hughes and Madden 1992, 1993; Madden et al. 2007).

We tested each sample individually using molecular assays (quantitative real-time polymerase chain reaction, or qRT-PCR) to acquire accurate diagnostic information. We tested for GLRaV-1, -2 and -3, GRBV, grapevine virus $A$ and $B$ (GVA, GVB), grapevine fleck virus (GFkV) and GFLV. Samples consisted of either four petioles or four canes (equivalent when using qRT-PCR for viruses in this survey) from each individually tested vine. Primers used were courtesy of FPS (Klaassen et al. 2011; Weber et al. 2002).

The survey data were subjected to three analyses to compare samples originating from older vineyards to those originating from vineyards planted between 2011 and 2014 with CGR\&C program material. First, we analyzed the percentage of positive vines for each virus tested in each planting year range. Second, we performed a distributional analysis (Madden et al. 2007). Third, we analyzed the presence of mixed infections in the surveyed vines because many viruses regulated by the CGR\&C program may exist as mixed infections in a single vine. Some viruses are synergistic (interacting with one another and producing dramatic increases in symptoms), potentially leading to greater economic impact (Syller 2012).

\section{Value of certified stock confirmed}

At the block level, the percentage of positive vines for each virus tested ranged from $0 \%$ to $100 \%$; each block contained only a subset of the eight viruses. On average, more viruses were present in old material than in recently planted certified material (fig. 1).

The distributional analysis (fig. 2) shows the frequency of different levels of infection. For example, in
TABLE 1. Planting years and history of surveyed vineyard blocks

\begin{tabular}{|c|c|}
\hline $\begin{array}{l}\text { Planting year } \\
\text { range }\end{array}$ & Surveyed vineyard blocks \\
\hline 1880-1980 & $\begin{array}{l}\text { Many blocks replanted on AXR-1 and St. George in response to an epidemic } \\
\text { of grape phylloxera (Daktulosphaira vitifoliae), an aphidlike root pest (Wolpert } \\
\text { et al. 1994). }\end{array}$ \\
\hline 1981-1995 & $\begin{array}{l}\text { Many blocks replanted due to the failure of AXR-1 to phylloxera biotype B } \\
\text { (Wolpert et al. 1994). }\end{array}$ \\
\hline 1996-2010 & $\begin{array}{l}\text { AXR-1 failure-related replacement vines planted on rootstocks of American } \\
\text { species parentage after viruses in infected scion mother material expressed } \\
\text { symptoms previously masked by AXR-1 and St. George. }\end{array}$ \\
\hline $2011-2014$ & $\begin{array}{l}2008-2009 \text { recession resulted in many blocks in fallow, which have since } \\
\text { been planted/replanted with certified material. }\end{array}$ \\
\hline
\end{tabular}

the 1880-1980 planting year range, seven blocks had $80 \%$ infection by GLRaV-2. In that year range, there was a relatively even number of blocks infected at the different percentage levels for the eight viruses. This is considered a uniform or even distribution.

Infection in the later planting year ranges was not evenly distributed at different levels; most blocks had low incidence, and in the planting year range 20112014 the incidence was mostly zero. The incidences in certified material planted in year range 2011-2014 of GFLV, GLRaV-3, GVA and GRBV (fig. 2) were likely related to spread by insects and nematodes (Bahder et al. 2016; Golino et al. 2002; Raski and Hewitt 1960; Tsai et al. 2008) and the recent discovery of GRBV (Al Rwahnih et al. 2013).

Of the vines tested from vineyards planted between 1880 and $1980,85 \%$ contained mixed infections. None of the vines in the 2011-2014 planting year range

\section{The benefit of using certified material sourced from virus-tested, monitored vines is seen in the absence of mixed infections.}

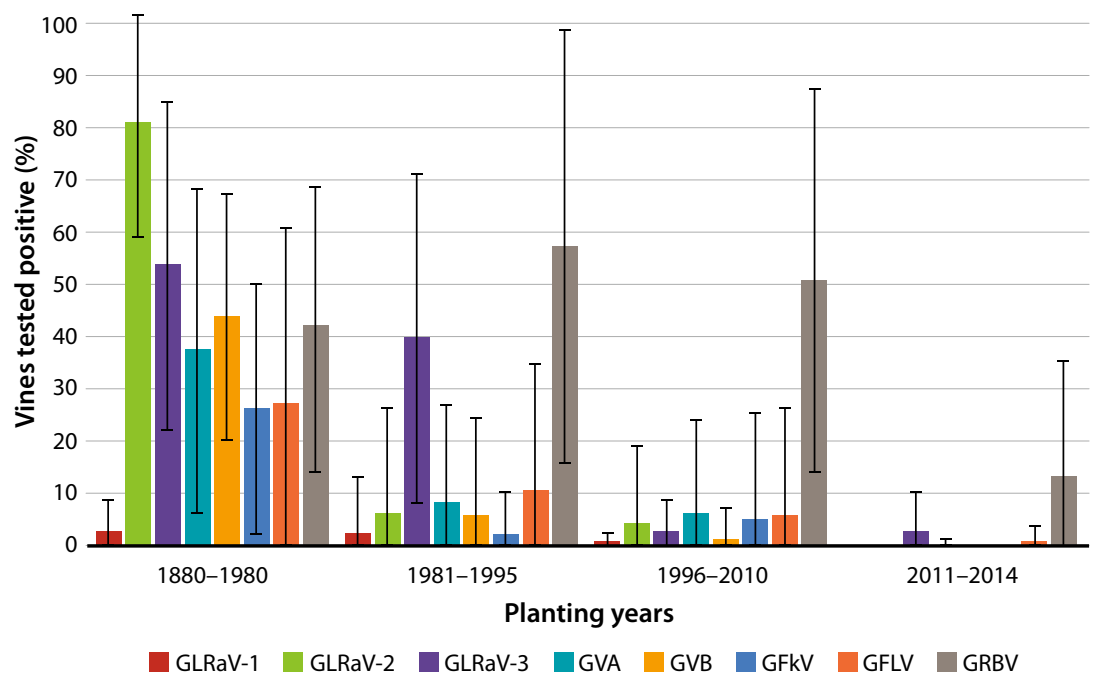

FIG. 1. Average percentage of positive vines for each virus tested in each planting year range. Standard error bars are in black. 

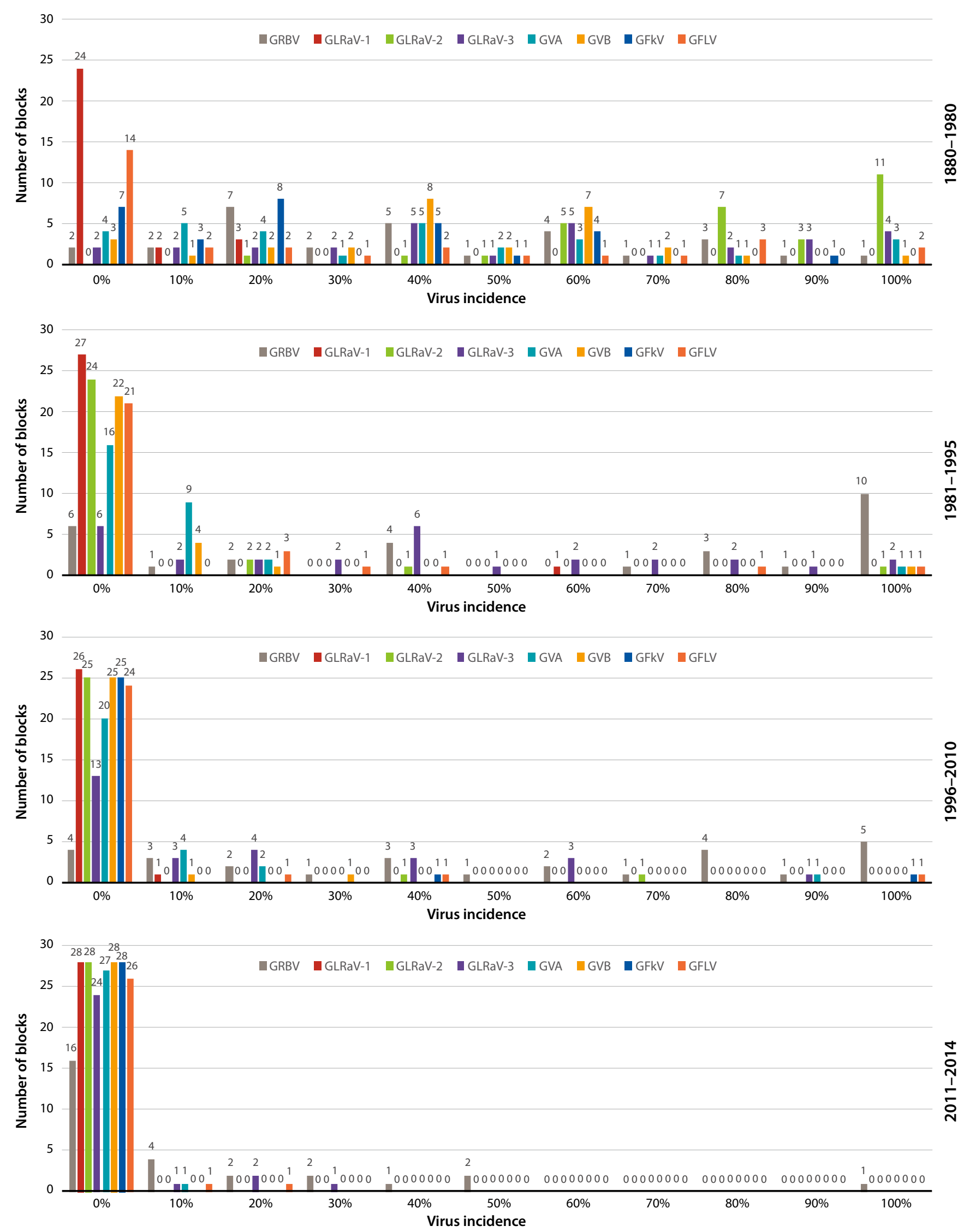

FIG. 2. Distributional analysis showed an even distribution of viruses in material planted between 1880 and 1980, while certified material planted between 2011 and 2014 showed predominantly zero infection. The few viruses present in certified material were viruses with known vectors and GRBV, which was unregulated until 2013. 

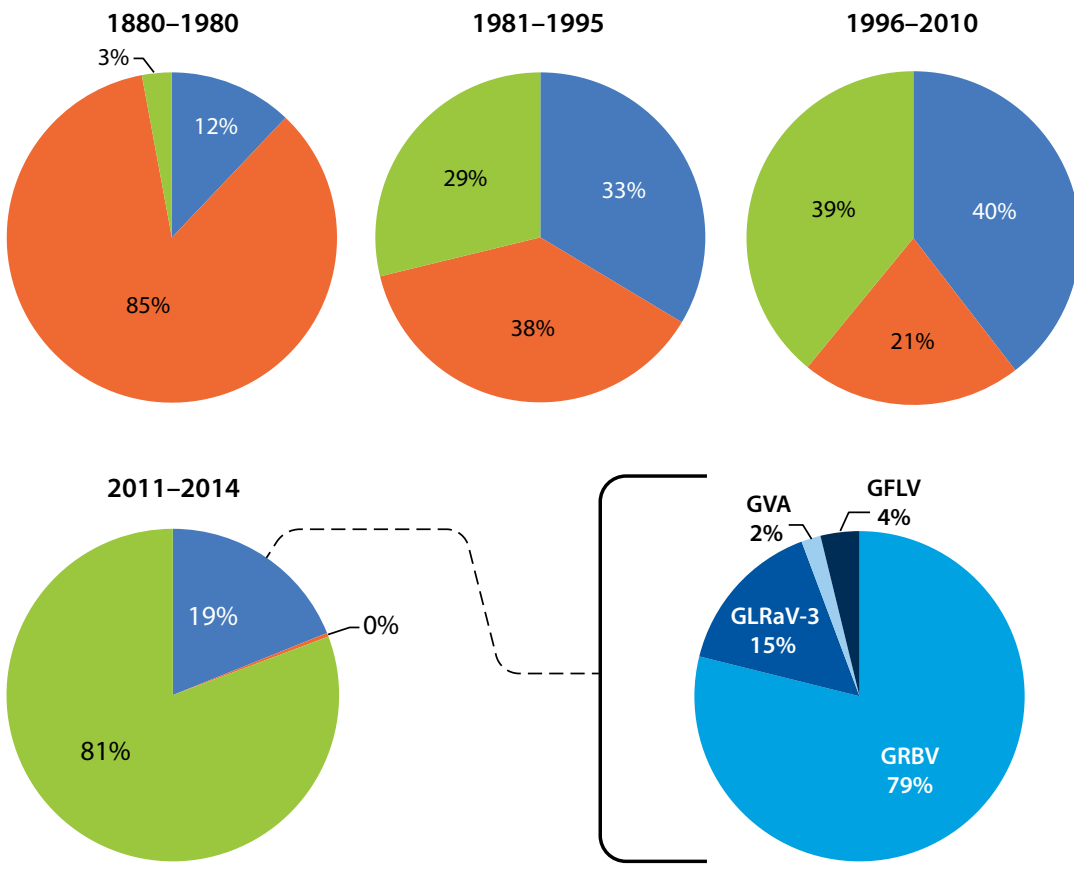

Mixed infections

Single infections

Virus negative

FIG. 3. Mixed infections were predominant in older vineyards. Recently planted certified vines did not have mixed infections. Only $19 \%$ of recently planted certified material had single infections and of those $79 \%$ were GRBV, a recently discovered virus, $15 \%$ were GLRaV-3, an insect transmitted virus and $4 \%$ were GFLV, a nematode-transmitted virus. contained mixed infections (fig. 3). More than $80 \%$ of the certified vines tested negative for all eight viruses, and the remaining approximately $20 \%$ of vines contained single virus infections. Of those single infections in new material, nearly $80 \%$ tested positive for GRBV, which was not regulated by the CGR\&C program until 2013 , and $15 \%$ tested positive for GLRaV-3, which is spread by mealybugs and scale insects.

The results of this survey suggest that there are risks associated with the use of nonregulated vineyard material for establishment of new vineyards. Without regulated sampling, screening and monitoring provided by the CGR\&C program as well as the research involved in discovering viruses, future planting material would decline as viral infections spread. CA

\section{K.L. Arnold is UC Cooperative Extension (UCCE) Orchard and} Vineyard Systems Advisor, Stanislaus County; N. McRoberts is Associate Professor of Plant Pathology, Quantitative Biology and Epidemiology Lab, Plant Pathology Department, UC Davis; M.L. Cooper is UCCE Viticulture Farm Advisor, Napa County; R. Smith is UCCE Viticulture Farm Advisor, Sonoma County; and D.A. Golino is Director of Foundation Plant Services, Foundation Plant Services and Plant Pathology Department, UC Davis.

This project was supported by the American Vineyard Foundation. We acknowledge the invaluable assistance of the staff, students and faculty at Foundation Plant Services, UC Davis, and the laboratory guidance of Vicki Klaassen. Additionally, we want to thank the North Coast wine grape growers for providing access to their vineyards.

\section{References}

Al Rwahnih M, Daubert S, Golino D, et al. 2015. Comparison of next-generation sequencing versus biological indexing for the optimal detection of viral pathogens in grapevine. Phytopathology 105(6):758-63.

Al Rwahnih M, Dave A, Anderson MM, et al. 2013. Association of a DNA virus with grapevines affected by red blotch disease in California. Phytopathology 103(10):1069-76.

Al Rwahnih M, Golino D, Rowhani A. 2016. First report of Grapevine Pinot gris virus infecting grapevine in the United States. Plant Dis 100(5):1030.

Al Rwahnih M, Rowhani A Golino DA. 2015. First report of Grapevine red blotch-associated virus in archival grapevine material from Sonoma County, California. Plant Dis 99(6):895.

Alley L, Golino D. 2000. The origins of the grape program at Foundation Plant Materials Service. In: Proc Am Soc Enol Viticult 50th Anniv Mtg, Jun 19-23, 2000. Seattle, Washington. p 222-30.
Arnold KL, Golino DA, McRoberts N. 2017. A synoptic analysis of the temporal and spatia aspects of grapevine leafroll disease in an historic Napa vineyard and experimental vine blocks. Phytopathology 107(4):418-26.

Bahder BW, Zalom F, Jayanth M Sudarshana MR. 2016. Phylogeny of geminivirus coat protein sequences and digital PCR aid in identifying Spissistilus festinus (Say) as a vector of Grapevine red blotch-associated virus. Phytopathology 106(10):1223-30.

Fuller KB, Alston JM, Golino DA. 2015. The economic benefits from virus-screening: A case study of grapevine leafroll in the north coast of California. Am J Enol Viticult 66(2):112-20.

Goheen A, Cook JA. 1959. Leafroll (red-leaf or rougeau) and its effects on vine growth, fruit quality, and yields. Am J Enol Viticult 10(4):173-81.
Golino DA, Fuchs M, Sim S, et al. 2017. Improvement of grapevine planting stock through sanitary selection and pathogen elimination. In: Meng B, Martelli GP, Golino DA, Fuchs M (eds.) Grapevine Viruses: Molecular Biology, Diagnostics, and Management. Springer. p 561-80.

Golino D, Sim S, Gill R, Rowhani A. 2002. California mealybugs can spread grapevine leafrol disease. Calif Agr 56(6):196-201. https://doi.org/10.3733/ ca.v056n06p196

Hughes G, Madden L. 1992. Aggregation and incidence of dis ease. Plant Pathol 41(6):657-60. Hughes G, Madden L. 1993 Using the beta-binomial distribution to describe aggregated patterns of disease incidence. Phytopathology 83(7):759-63.

Klaassen VA, Sim ST, Dangl G, et al. 2011. Vitis californica and Vitis californica $\times$ Vitis vinifera hybrids are hosts for Grapevine leafrollassociated virus- 2 and -3 and Grapevine virus A and B. Plant Dis 95(6):657-65.
Madden LV, Hughes G, Bosch F. 2007. The Study of Plant Disease Epidemics. St. Paul, MN: APS Press.

Martelli G. 2014. Directory of virus-like diseases of the grapevine and their agents. J Plant Pathol 96(suppl. 1):1-136.

McRoberts N, Hughes G, Madden L. 2003. The theoretical basis and practical application of relationships between different disease intensity measurements in plants. Ann Appl Biol 142(2):191-211.

Olmo HP. 1951. A proposed program for the introduction, improvement and certification of healthy grape varieties. Wines \& Vines 32(7):7-9.

Raski D, Hewitt WB. 1960. Experiments with Xiphinema index as a vector of fanleaf of grapevines. Nematologica 5(3):166-70.

Ricketts KD, Gomez MI, Atallah SS, et al. 2015. Reducing the economic impact of grapevine leafroll disease in California: Identifying optimal disease management strategies. Am J Enol Viticult 66(2):138-47.
Ricketts KD, Gómez MI, Fuchs MF, et al. 2017. Mitigating the economic impact of grapevine red blotch: Optimizing disease management strategies in U.S. vineyards. Am J Enol Viticult 68(1):127-35

Rowhani A, Uyemoto JK, Golino DA, Martelli GP. 2005. Pathogen testing and certification of Vitis and Prunus species. Annu Rev Phytopathol (43):261-78.

Syller J. 2012. Facilitative and antagonistic interactions between plant viruses in mixed infections. Mol Plant Pathol 13(2):204-16

Tsai C-W, Chau J, Fernandez $\mathrm{L}$, et al. 2008. Transmission of Grapevine leafroll-associated virus 3 by the vine mealybug (Planococcus ficus). Phytopathology 98(10):1093-8.

Weber E, Golino D, Rowhani A. 2002. Laboratory testing for grapevine diseases. Prac Winery Vineyard J Jan/Feb:1-5.

Wolpert J, Walker A, Weber E, et al. 1994. Rootstocks and phylloxera: A status report for coastal and northern California. Viticult Notes (6):1-17. 